\title{
Physiological Response of Advanced Lines of Rice under Water Deficit in Campeche, Mexico
}

\author{
Mónica Beatriz López-Hernández ${ }^{1}$ (), Jesús Arreola-Enríquez², Antonio Villalobos-González ${ }^{3 *}$ (), \\ Luis Leonardo Pinzón-López ${ }^{4}$ (1) , Edwin Javier Barrios-Gómez5 , Saúl Espinosa-Zaragoza6 (i), \\ Diana Sanzón-Gómez ${ }^{7}$ (i)
}

\author{
${ }^{1}$ Instituto Tecnológico de Chiná, Chiná, México \\ ${ }^{2}$ Colegio de Postgraduados, Sihochac, México \\ ${ }^{3}$ Instituto Nacional de Investigaciones Forestales, Agrícolas y Pecuarias, Campo Experimental Edzná, Campeche, México \\ ${ }^{4}$ Instituto Tecnológico de Conkal, Conkal, México \\ ${ }^{5}$ Instituto Nacional de Investigaciones Forestales, Agrícolas y Pecuarias, Campo Experimental Zacatepec, Morelos, México \\ ${ }^{6}$ Universidad Autónoma de Chíapas, Facultad de Ciencias Agrícolas, Huehuetán, México \\ ${ }^{7}$ Universidad de Guanajuato, Campus Irapuato-Salamanca, Irapuato, México \\ Email: *villalobos.antonio@inifap.gob.mx
}

How to cite this paper: López-Hernández, M.B., Arreola-Enríquez, J., Villalobos-González, A., Pinzón-López, L.L., Barrios-Gómez, E.J., Espinosa-Zaragoza, S. and Sanzón-Gómez, D. (2020) Physiological Response of Advanced Lines of Rice under Water Deficit in Campeche, Mexico. Agricultural Sciences, 11, 932-945.

https://doi.org/10.4236/as.2020.1110061

Received: September 10, 2020

Accepted: October 19, 2020

Published: October 22, 2020

Copyright $\odot 2020$ by author(s) and Scientific Research Publishing Inc. This work is licensed under the Creative Commons Attribution International License (CC BY 4.0).

http://creativecommons.org/licenses/by/4.0/

\begin{abstract}
Yields of rice (Oryza sativa L.) respond to complex interactions between the genotype and the environment; rice has the particularity of being a semi-aquatic crop, and as a result of this, it presents lower adaptation to the limiting water content of soil and is extremely sensitive to stress from drought; therefore, it is the most important limiting factor in rice production. The objective of this study was to research the physiological response of rice genotypes to water stress. The grain yield and its components, leaf area and transpiration efficiency under irrigation (I) and drought (D) were evaluated in eight advanced lines from the nursery of the Latin American Fund for Irrigated Rice (Fondo Latinoamericano para Arroz de Riego, FLAR) and a control variety of rice. The experiment was established in Campeche, in the 2015 autumn-winter cycle. The grain yield and its components, as well as the leaf area were greater under irrigation conditions than under drought. The transpiration from the water stress was reduced and the plants under drought increased their transpiration efficiency. The genotypes P-V 2006 and P-V 2009 were identified, with genealogies FL05392-3P-12-2P-2P-M and FL082243P-2-1P-3P-M, respectively, as the most outstanding compared to the rest of the genotypes in the grain yield and its components, leaf area, total root biomass, and transpiration efficiency.
\end{abstract}

\section{Keywords}

Oryza sativa L., Yield, Drought 


\section{Introduction}

Cultivation of rice (Oryza sativa L.) in Mexico occupies the fourth place after corn, bean and wheat in terms of surface, production and consumption, and is grown in an approximate area of 42,310 ha with a national average grain yield of $5.8 \mathrm{t} \cdot \mathrm{ha}^{-1}$ [1]. Of this surface, $75 \%$ is cultivated under conditions of irrigation or permanent flooding during the cycle, with an average yield of $6.4 \mathrm{t} \cdot \mathrm{ha}^{-1}$ and the remaining $25 \%$ is cultivated under rainfed conditions with average yields of 3.8 t.ha ${ }^{-1}$ [1]. However, since 2001, the national production has decreased as a result of the disarticulation of the rice chain, which is why there is use for importing it, and $85 \%$ of the national consumption of thin grain rice was imported in 2015 [2] [3] [4]. Therefore, the National Institute of Forest, Agricultural and Livestock Research (Instituto Nacional de Investigaciones Forestales Agrícolas y Pecuarias, INIFAP) in Mexico and the Latin American Fund for Irrigated Rice (Fondo Latinoamericano de Arroz de Riego, FLAR) in Colombia work together for the stockpiling, selection and biometric evaluation of materials of rice with thing long grain under the environmental conditions of the dry and humid tropics in Mexico [4].

Sowing rainfed rice is carried out in the humid tropics of the southeastern region of Mexico, which stretches from the Papaloapan Basin in part of the states of Veracruz and Oaxaca, the region of La Chontalpa (Tabasco) to the areas of Palizada and Yohaltun in the state of Campeche, zone considered as vulnerable to climate change due to the frequent losses of rice harvests caused by the "intraestival" summer drought and/or torrential rains in the autumn that cause flooding and lodging of rice crops [5]. Drought is considered as a deficit of sufficient water availability to cause a decrease in the yield of crops [6]. On the other hand, the magnitude of the decrease in the grain yield depends on the duration of the drought and severity of stress [7], in addition to the growth stage of the crop [8]. Thus, the sensitivity of rice (Oryza sativa L.) to drought increases, when the drought takes place in the flowering period [9]. As consequence, the water content is considerably reduced in the reproductive stage in plant cells, showing symptoms of withering and loss of turgidity, which has an effect on a decrease of the gas exchange and photosynthesis of the plant and, finally, on the grain yield [10].

The studies in advanced lines of rice from FLAR are directed toward parameters of stability of yields [11]. However, the low yields are related to climate change, and studies of the materials with different abiotic stresses are required for this, in this case, water stress to guarantee availability of materials with resistance or tolerance to drought [12]. Therefore, the objective of this study was to research the response of eight advanced lines and a control variety of rice (Oryza sativa L.), on grain yield and its components, leaf area, total transpiration and transpiration efficiency under irrigation (I) and drought (D) in a greenhouse, with the aim of selecting high yield materials with tolerance to drought and making recommendations to farmers of the region. 


\section{Materials and Methods}

\subsection{Soil and Climate in the Study Area}

The experiment was established in the 2015 autumn-winter cycle in a greenhouse of Colegio de Postgraduados, Campus Campeche, five meters high with a white mesh roof, however, to avoid the incidence of rain, a polyethylene cover was placed at a height of three meters. To allow the plants to be exposed to room temperature, air was allowed into the greenhouse, lifting the mesh at the ends. Colegio de Postgraduados, Campus Campeche, located in the Haltunchén-Edzná road, km 17.5, Sihochac, municipality of Champotón, Campeche, Mexico $\left(17^{\circ} 49^{\prime} \mathrm{N}, 91^{\circ} 08^{\prime}\right.$ and 27 masl). The locality of Sihochac has warm subhumid type climate with summer rains [Awo (w)], with a mean precipitation of $1500 \mathrm{~mm}$ and mean annual temperature of $26^{\circ} \mathrm{C}$, with maximum temperatures of $42^{\circ} \mathrm{C}$ and minimum of $10^{\circ} \mathrm{C}$ [13]. Soil analysis was carried out in the Soil Laboratory of Universidad Autónoma Chapingo (Table 1).

\subsection{Genetic Material in Evaluation}

Eight advanced lines (F6) of rice and a control variety (El Silverio) were included. The lines presented characteristics of high yield and resistance to the vector of the white leaf virus (Tagosodes oryzicolus) and rice "burn" (Magnaporthe oryzae, anamorphic Pyricularia oryzae), higher quality of grain, defined by its amylose content, appearance of the processed grain, high recovery of full grains and tolerance to the delay in harvest [14]. The lines came from the nurseries of the Latin American Fund for Irrigated Rice (FLAR, Palmira, Colombia). The genetic material was preselected by grain yield in humid, subhumid and dry tropical environments in the spring-summer cycle (S-S) of 2012 by researchers from INIFAP in different localities (Palizada, Campeche; Zacatepec, Morelos; Cárdenas, Tabasco; and Tecomán, Colima, Mexico). The control variety was chosen for the following characteristics: The Silverio is a medium grain variety with $10 \%$ of "chalkiness" and highly versatile, it can be grown under rainfed conditions or rainfed with auxiliary irrigation in the south-east humid tropic (Veracruz, Oaxaca, Tabasco, Campeche and Chiapas) and sub-humid northeast (Tamaulipas), also under irrigation in the Pacific dry tropic (Nayarit, Jalisco, Colima and Michoacán). Its average yield potential is around $6 \mathrm{t} \cdot \mathrm{ha}^{-1}$ under rainfed conditions, of $7 \mathrm{t} \cdot \mathrm{ha}^{-1}$ in rainfed with auxiliary irrigation and $8 \mathrm{t} \cdot \mathrm{ha}^{-1}$ under irrigation. Due to its growth cycle characteristics and intermediate height (130 to 135 days and $91 \mathrm{~cm}$ ), is well suited to rainfed conditions [4] (Table 2).

\subsection{Study Factors and Experimental Design}

The experiment consisted in two treatments of soil moisture; irrigation (I) that consisted in maintaining the soil moisture close to field capacity (FC) and drought (D) with the suspension of irrigation at 65 days after sowing (das) and until physiological maturity. The day of onset of drought was chosen based on 
Table 1. Physical and chemical characteristics of the soil used in the experiment to study the physiological response of advanced lines of rice to water stress. Autumn-winter cycle 2015. Campeche, Mexico.

\begin{tabular}{cccccccccc}
\hline \multicolumn{10}{c}{ Physical and chemical characteristics } \\
\hline Texture & AD & FC & PPM & pH & EC & OM & N & P & K \\
\hline & $\left(\mathrm{t} \cdot \mathrm{m}^{-3}\right)$ & $\%$ & $\%$ & - & $\mathrm{dS} \cdot \mathrm{m}^{-1}$ & $\%$ & $\mathrm{mg} \cdot \mathrm{Kg}^{-1}$ & $\mathrm{mg} \cdot \mathrm{Kg}^{-1}$ & $\mathrm{mg} \cdot \mathrm{Kg}^{-1}$ \\
Clay & 1.23 & 40.7 & 32.2 & 7.2 & 0.72 & 3.1 & 23.8 & 6.3 & 536 \\
\hline
\end{tabular}

The texture was determined, Bouyoucos hydrometer method; AD: apparent density, test tube method $\left(\mathrm{t} \cdot \mathrm{m}^{-3}\right)$; FC: field capacity, pressure cooker method equivalent to $0.3 \mathrm{~atm}$ PPM: percentage of permanent withering, pressure membrane method equivalent to $15 \mathrm{~atm}$; $\mathrm{pH}$, electronic $\mathrm{pH}$ gauge; EC: electric conductivity, bridge method of electric conductivity; OM: organic matter, Walkley-Black method; N: total nitrogen, vapor dragging; P: phosphorus, Olsen method; K: potassium, flame emission spectrophotometry method.

Table 2. Genetic material of rice preselected by yield, used in the experiment to study the physiological response of advanced lines of rice to water stress. Autumn-winter 2015 cycle. Campeche, Mexico.

\begin{tabular}{ccccc}
\hline No. of genotype & Genealogy & Origin & Grain yield $\left(\mathrm{t} \cdot \mathrm{ha}^{-1}\right)$ & Days to anthesis \\
\hline 1 & FL04621-2P-1-3P-3P-M & P-V 2005 & 6.8 & 85 \\
2 & FL05392-3P-12-2P-2P-M & P-V 2006 & 13.2 & 90 \\
3 & FL06747-4P-10-5P-3P-M & P-V 2007 & 10.5 & 89 \\
4 & FL07201-6P-5-3P-3P-M & P-V 2008 & 9.4 & 84 \\
5 & FL08224-3P-2-1P-2P-M & P-V 2009 & 10.9 & 90 \\
6 & FL08378-3P-5-2P-2P-M & P-V 2009 & 11.4 & 87 \\
7 & FL08224-3P-2-1P-3P-M & P-V 2009 & 15.9 & 92 \\
8 & FL10129-12P-4-2P-3P-M & P-V 2011 & 12.1 & 88 \\
9 & "El Silverio" (Testigo) & P-V 2011 & 12.0 & 91 \\
\hline
\end{tabular}

The lines come from the nurseries of the Latin American Fund for Irrigated Rice (FLAR), Palmira, Colombia.

the fact that the reproductive stage of the crop begins at 65 days. Sowing was done on February 12, 2015, with a rice seed of each variety per experimental unit, with a fertilization dose of 180-40-40; a third of the nitrogen and all the phosphorus and potassium were applied during sowing; a second third of the nitrogen at the beginning of the stage of clustering, 25 days after sowing (das), and the rest of the nitrogen during filling, 78 days after sowing (das), with urea as a nitrogen source, triple calcium superphosphate and potassium chloride as sources of phosphorus and potassium, respectively [14].

A complete random block design with three repetitions was used in irrigation and three in drought; the experimental unit consisted in an individual plant per PVC tube of $1 \mathrm{~m}$ high and $10 \mathrm{~cm}$ of diameter. A cylindrical polyethylene bag of the same dimensions was placed in each PVC tube and it was filled with previously sterilized soil; the soil was taken to FC and the initial weight at FC was defined (IWFC) in each experimental unit. In the irrigation treatment (I) the 
tubes were weighed every third day, to calculate the amount of water lost from evapotranspiration (ET) and add the water required, to take the soil from each tube to IWFC and maintain the level of moisture close to FC from sowing to physiological maturity of plants; the same procedure was done in the drought treatment (D) as in irrigation; water was added to the tubes, to take the soil to FC and the soil water content was maintained close to FC until 65 days after sowing (das); from this date the application of water was suspended and the weight was recorded only at 114 das, date when recovery irrigation was applied. The amount of ET ( $\mathrm{g}$ of water) in each tube was calculated as the difference between initial weights of the tube to FC $(\mathrm{kg})$ - weight of the tube in each date of weighing $(\mathrm{kg})$. The transpiration per plant $(\mathrm{T})$ was calculated as the difference between ET - direct evaporation from the soil (ES) estimated in control tubes without plant in each weighing; the total accumulated transpiration was calculated when adding the $\mathrm{T}$ obtained in each weighing from sowing to physiological maturity. The plants were kept under a polyethylene cover at a height of $3.0 \mathrm{~m}$, to avoid the incidence of rain on the experiment and allow the plants to be exposed to the environmental temperature.

\subsection{Study Variables and Statistical Analysis}

The following variables were evaluated: grain yield (GY, g) which was obtained when determining the weight of the grain after dekernelling of all the panicles of the plants harvested; the final aerial biomass (FABM, g) was defined when obtaining the total dry weight of the aerial part of the plant when reaching physiological maturity; the harvest index (HI) was calculated as the quotient between grain yield (GY, g) and final aerial biomass (g):

$$
(\mathrm{HI}=\mathrm{GY} / \mathrm{BM})
$$

the number of panicles per plant (NPP) was determined when counting the number of panicles in each experimental unit; the number of grains per panicle $\left(\mathrm{NGP}^{-1}\right)$ was determined when counting the number of grains in each panicle per plant and averaging the number of grains between the total panicles per plant; the weight of 1000 grains (WTG, g) was obtained when weighing 1000 grains taken randomly from each experimental unit of the sample used to determine the grain yield; the days until flowering or anthesis (A) was recorded when $50 \%$ of the panicles of each experimental unit showed spikelets with exposed anthers and in dehiscence; the days until physiological maturity (PM) were found when $80 \%$ of the plants in each experimental unit had lost the green color of their aerial organs and presented a characteristic hay color of each genotype; the plant height $(\mathrm{PH}, \mathrm{cm})$ was determined by measuring the height from the soil surface to the terminal spikelet in each experimental unit in the stage of physiological maturity; for the green leaf area $\left(\mathrm{GLA}, \mathrm{cm}^{2}\right)$, the area $\left(\mathrm{cm}^{2}\right)$ of each leaf from the main stalk of each experimental unit was determined by multiplying the length $(\mathrm{cm}) \times$ the width $(\mathrm{cm}) \times 0.75$, every five days from 18 to 109 days 
after sowing (das); the total transpiration per plant (TT, $\mathrm{kg}$ ) was calculated when adding the transpiration determined between consecutive measurements during the biological cycle of each plant; and the transpiration efficiency to produce total biomass of the plant (ETBMT, g of BMT/ $\mathrm{kg}$ of $\mathrm{H}_{2} \mathrm{O}$ transpired) was calculated by dividing the total biomass between the amount of water transpired by the plant at the end of the biological cycle.

$$
\text { (ETBMT }=\mathrm{g} \text { of } \mathrm{BMT} / \mathrm{kg} \text { of } \mathrm{H}_{2} \mathrm{O} \text { transpired) }
$$

ANOVA was carried out with the data for all the variables with the SAS software, Version 9.1, for Windows [15] individually for each treatment of soil moisture and in a combined way, to determine the significance of genotype $\mathrm{x}$ environment interaction. The means comparison was carried out with DMS ( $\mathrm{p} \leq$ $0.05)$.

\section{Results}

\subsection{Soil Moisture Content}

The soil moisture content in the irrigation treatment was kept close to field capacity (FC), during the entire experiment; in the drought treatment the soil water content was kept close to FC until beginning the drought treatment at 65 days after sowing (das). In drought the soil water content reached values under the permanent wilting Point (PWP), as the cultivation cycle happened (Figure $1)$.

\subsection{Grain Yield and Its Components}

In irrigation, the statistical analysis of the data detected highly significant differences ( $p \leq 0.01$ ) between genotypes for grain yield (GY), final aerial biomass (FABM), harvest index (HI), number of panicles per plant (NPP), number of grains per panicle (NGP), weight of 1000 grains (WTG), days to anthesis (DA) and plant height $(\mathrm{PH})$ (Table 3$)$. The grain yield and its components in irrigation presented high variability between genotypes. The greatest variation was observed in the grain yield, final aerial biomass, number of grains per panicle and plant height. Genotypes 2 and 7 presented the highest grain yield in addition to final aerial biomass, harvest index, number of panicles per plant, weight of one thousand grains, and plant height (Table 3).

In drought the statistical analysis of the data detected highly significant differences ( $p \leq 0.01$ ) between genotypes for grain yield (GY), final aerial biomass (FABM), harvest index (HI), number of panicles per plant (NPP), number of grains per panicle (NGP), weight of 1000 grains (WTG), days to anthesis (DA), days to physiological maturity (DPM) and plant height (Table 4). Genotypes 2 and 7 presented the highest grain yield accompanied by the harvest index, number of panicles per plant, and plant height. Genotype 2 presented a higher final aerial biomass, number of grains per panicle and weight of one thousand grains, compared to the rest of the genotypes (Table 4). 
The combined statistical analysis of irrigation and drought detected highly significant differences $(\mathrm{p} \leq 0.01)$ between levels of humidity, between genotypes and interaction levels of humidity-genotypes in all the variables assessed (Table 5). Drought reduced grain yield, final aerial biomass, harvest index, number of panicles per plant, number of grains per panicle, weight of one thousand grains, and plant height (Table 5). The reduction resulting from the water stress effect was higher in the final aerial biomass (52\%), grain yield (45\%), number of panicles per plant (36\%), weight of one thousand grains (31\%), plant height (28\%), number of grains per panicle (27\%), and harvest index (15\%) (Table 5).

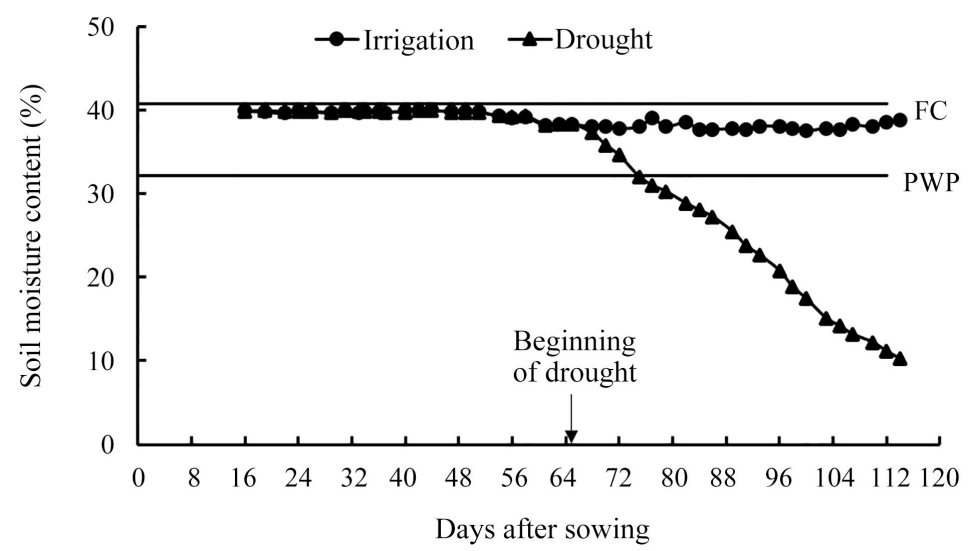

Figure 1. Water content of the soil in irrigation and drought from 8 to 120 days after sowing (das), under greenhouse conditions. Field Capacity (FC), Permanent Wilting Point (PWP) Autumn-winter cycle 2015. Campeche, Mexico.

Table 3. Grain yield and its components, days to anthesis and plant height of rice genotypes under irrigation. Autumn-winter cycle 2015. Campeche, Mexico.

\begin{tabular}{ccccccccc}
\hline $\begin{array}{c}\text { No of } \\
\text { genotype }\end{array}$ & $\begin{array}{c}\text { GY } \\
\left(\mathrm{g} \cdot \mathrm{p}^{-1}\right)\end{array}$ & $\begin{array}{c}\text { FABM } \\
\left(\mathrm{g} \cdot \mathrm{p}^{-1}\right)\end{array}$ & $\begin{array}{c}\text { HI } \\
(\%)\end{array}$ & NPP & NGP & $\begin{array}{c}\text { WTG } \\
\left(\mathrm{g} \cdot \mathrm{p}^{-1}\right)\end{array}$ & DA & $\begin{array}{c}\text { PH } \\
(\mathrm{cm})\end{array}$ \\
\hline 7 & $32 \mathrm{a}$ & $64 \mathrm{a}$ & $50 \mathrm{a}$ & $16 \mathrm{a}$ & $194 \mathrm{a}$ & $39 \mathrm{a}$ & $89 \mathrm{bcd}$ & $97 \mathrm{a}$ \\
2 & $30 \mathrm{~b}$ & $60 \mathrm{~b}$ & $51 \mathrm{a}$ & $15 \mathrm{a}$ & $177 \mathrm{~b}$ & $35 \mathrm{~b}$ & $91 \mathrm{ab}$ & $95 \mathrm{ab}$ \\
6 & $24 \mathrm{c}$ & $45 \mathrm{c}$ & $47 \mathrm{~cd}$ & $13 \mathrm{~b}$ & $143 \mathrm{~d}$ & $34 \mathrm{c}$ & $88 \mathrm{cde}$ & $82 \mathrm{e}$ \\
5 & $21 \mathrm{~d}$ & $36 \mathrm{~d}$ & $43 \mathrm{f}$ & $10 \mathrm{~d}$ & $161 \mathrm{c}$ & $31 \mathrm{~d}$ & $91 \mathrm{ab}$ & $87 \mathrm{c}$ \\
4 & $17 \mathrm{e}$ & $32 \mathrm{e}$ & $46 \mathrm{de}$ & $9 \mathrm{e}$ & $146 \mathrm{~d}$ & $30 \mathrm{de}$ & $87 \mathrm{de}$ & $73 \mathrm{f}$ \\
1 & $15 \mathrm{f}$ & $29 \mathrm{f}$ & $48 \mathrm{bc}$ & $9 \mathrm{de}$ & $138 \mathrm{e}$ & $29 \mathrm{e}$ & $86 \mathrm{e}$ & $88 \mathrm{c}$ \\
3 & $14 \mathrm{~g}$ & $26 \mathrm{~g}$ & $47 \mathrm{~d}$ & $11 \mathrm{c}$ & $133 \mathrm{f}$ & $26 \mathrm{f}$ & $91 \mathrm{ab}$ & $93 \mathrm{~b}$ \\
9 (Control) & $13 \mathrm{~h}$ & $23 \mathrm{~h}$ & $45 \mathrm{e}$ & $7 \mathrm{f}$ & $118 \mathrm{~g}$ & $26 \mathrm{f}$ & $92 \mathrm{a}$ & $82 \mathrm{de}$ \\
8 & $12 \mathrm{~h}$ & $23 \mathrm{~h}$ & $49 \mathrm{~b}$ & $6 \mathrm{f}$ & $113 \mathrm{~h}$ & $26 \mathrm{f}$ & $90 \mathrm{abc}$ & $86 \mathrm{~cd}$ \\
General Mean & 20 & 38 & 47 & 11 & 147 & 31 & 90 & 87 \\
DMS (p $\leq 0.05)$ & 0.8 & 1.1 & 1.3 & 1.1 & 3.1 & 1.3 & 2.7 & 3.8
\end{tabular}

Means with different letter in each column are statistically different (DMS, P $\leq 0.05$ ). GY: grain yield per plant; FABM: final aerial biomass; HI: harvest index; NPP: number of panicles per plant; NGP: number of grains per panicle; WTG: weight of one thousand grains; DA: days until flowering and and PH: plant height. ${ }^{*}$ The genotypes come from nurseries of the Latin American Fund for Irrigated Rice (Fondo Latinoamericano para Arroz de Riego, FLAR), Palmira, Colombia. 
Table 4. Grain yield and its components, days to flowering, days to physiological maturity and plant height of rice genotypes in drought. Autumn-winter cycle 2015. Campeche, Mexico.

\begin{tabular}{cccccccccc}
\hline $\begin{array}{c}\text { No of } \\
\text { genotype }\end{array}$ & $\begin{array}{c}\text { GY } \\
\left(\mathrm{g} \cdot \mathrm{p}^{-1}\right)\end{array}$ & $\begin{array}{c}\text { FABM } \\
\left(\mathrm{g} \cdot \mathrm{p}^{-1}\right)\end{array}$ & $\begin{array}{c}\mathrm{HI} \\
(\%)\end{array}$ & NPP & NGP & $\begin{array}{c}\text { WTG } \\
\left(\mathrm{g} \cdot \mathrm{p}^{-1}\right)\end{array}$ & DA & DPM & $\begin{array}{c}\text { PH } \\
(\mathrm{cm})\end{array}$ \\
\hline 7 & $14 \mathrm{a}$ & $26 \mathrm{a}$ & $45 \mathrm{a}$ & $11 \mathrm{a}$ & $123 \mathrm{a}$ & $27 \mathrm{a}$ & $100 \mathrm{abc}$ & $134 \mathrm{~d}$ & $72 \mathrm{ab}$ \\
2 & $14 \mathrm{~b}$ & $25 \mathrm{~b}$ & $45 \mathrm{a}$ & $10 \mathrm{~b}$ & $118 \mathrm{~b}$ & $25 \mathrm{~b}$ & $100 \mathrm{abc}$ & $142 \mathrm{abc}$ & $60 \mathrm{c}$ \\
6 & $10 \mathrm{e}$ & $16 \mathrm{e}$ & $40 \mathrm{~b}$ & $7 \mathrm{~d}$ & $104 \mathrm{e}$ & $23 \mathrm{c}$ & $94 \mathrm{e}$ & $139 \mathrm{~cd}$ & $67 \mathrm{bc}$ \\
5 & $12 \mathrm{c}$ & $21 \mathrm{c}$ & $45 \mathrm{a}$ & $5 \mathrm{f}$ & $113 \mathrm{c}$ & $20 \mathrm{~g}$ & $98 \mathrm{bcd}$ & $143 \mathrm{ab}$ & $66 \mathrm{bc}$ \\
4 & $10 \mathrm{e}$ & $16 \mathrm{e}$ & $42 \mathrm{~b}$ & $8 \mathrm{c}$ & $108 \mathrm{~d}$ & $20 \mathrm{f}$ & $95 \mathrm{ed}$ & $145 \mathrm{a}$ & $80 \mathrm{a}$ \\
1 & $11 \mathrm{~d}$ & $17 \mathrm{~d}$ & $38 \mathrm{c}$ & $7 \mathrm{~cd}$ & $112 \mathrm{c}$ & $21 \mathrm{e}$ & $103 \mathrm{abc}$ & $139 \mathrm{~cd}$ & $62 \mathrm{c}$ \\
3 & $11 \mathrm{~d}$ & $16 \mathrm{e}$ & $34 \mathrm{~d}$ & $6 \mathrm{e}$ & $103 \mathrm{e}$ & $22 \mathrm{~d}$ & $101 \mathrm{ab}$ & $141 \mathrm{bc}$ & $72 \mathrm{ab}$ \\
$9($ Control $)$ & $8 \mathrm{f}$ & $14 \mathrm{f}$ & $35 \mathrm{c}$ & $3 \mathrm{~g}$ & $86 \mathrm{~g}$ & $17 \mathrm{~h}$ & $96 \mathrm{ed}$ & $133 \mathrm{e}$ & $65 \mathrm{bc}$ \\
8 & $8 \mathrm{f}$ & $12 \mathrm{~g}$ & $36 \mathrm{~d}$ & $4.0 \mathrm{~g}$ & $97 \mathrm{f}$ & $16 \mathrm{i}$ & $97 \mathrm{cde}$ & $144 \mathrm{ab}$ & $63 \mathrm{bd}$ \\
General Mean & 11 & 18 & 40 & 7 & 107 & 21 & 98 & 140 & 67 \\
DMS (p $\leq 0.05)$ & 0.3 & 0.5 & 1.9 & 0.8 & 2.5 & 0.5 & 3 & 3.3 & 9.6 \\
\hline
\end{tabular}

Means with different letter in each column are statistically different (DMS, P $\leq 0.05)$. GY: grain yield per plant; FABM: final aerial biomass; HI: harvest index; NPP: number of panicles per plant; NGP: number of grains per panicle; WTG: weight of one thousand grains; DA: days until flowering; DPM: days until physiological maturity and PH: plant height. ${ }^{*}$ The genotypes come from nurseries of the Latin American Fund for Irrigated Rice (Fondo Latinoamericano para Arroz de Riego, FLAR), Palmira, Colombia.

Table 5. Grain yield and its components: days until flowering, days until physiological maturity and plant height, average of rice genotypes in irrigation and drought. Autumn-winter cycle 2015. Sihochac, Champotón, Campeche-Mexico.

\begin{tabular}{cccccccccc}
\hline Moisture Level & $\begin{array}{c}\text { GY } \\
\left(\mathrm{g} \cdot \mathrm{p}^{-1}\right)\end{array}$ & $\begin{array}{c}\text { FABM } \\
\left(\mathrm{g} \cdot \mathrm{p}^{-1}\right)\end{array}$ & $\begin{array}{c}\text { HI } \\
(\%)\end{array}$ & NPP & NGP & $\begin{array}{c}\text { WTG } \\
\left(\mathrm{g} \cdot \mathrm{p}^{-1}\right)\end{array}$ & DA & DPM & $\begin{array}{c}\text { PH } \\
(\mathrm{cm})\end{array}$ \\
\hline Irrigation & $20 \mathrm{a}$ & $38 \mathrm{a}$ & $47 \mathrm{a}$ & $11 \mathrm{a}$ & $147 \mathrm{a}$ & $31 \mathrm{a}$ & $90 \mathrm{~b}$ & $125 \mathrm{~b}$ & $87 \mathrm{a}$ \\
Drought & $11 \mathrm{~b}$ & $18 \mathrm{~b}$ & $40 \mathrm{~b}$ & $7 \mathrm{~b}$ & $107 \mathrm{~b}$ & $21 \mathrm{~b}$ & $98 \mathrm{a}$ & $140 \mathrm{a}$ & $67 \mathrm{~b}$ \\
DMS (p $\leq 0.05)$ & 0.4 & 0.4 & 1 & 0.2 & 1.1 & 0.3 & 2.5 & 2.4 & 1.5 \\
\hline
\end{tabular}

Means with different letter in each column are statistically different (DMS, P $\leq 0.05)$. GY: grain yield (g); FABM: final aerial biomass (g); HI: harvest index (\%); NP P-1: number of panicles per plant-1; NGP-1: number of grains per panicle-1; WTG: weight of one thousand grains; DA: days until anthesis; DPM: days until physiological maturity; and PH: plant height.

\subsection{Leaf Area}

In irrigation, the statistical analysis detected highly significant differences ( $\mathrm{p} \leq$ $0.01)$ between genotypes for the leaf area and statistical differences $(\mathrm{p} \leq 0.05)$ at 25 days after sowing (das) (Figure 2). Figure 2 shows the trend of the genotypes in irrigation on the increase of leaf area throughout development to later decrease because of the withering of lower leaves. In average of all the measurements carried out, genotypes 1, 2 and 7 were detected with the largest leaf area; on the contrary, genotypes $3,6,8$ and 9 presented the smallest leaf area. 


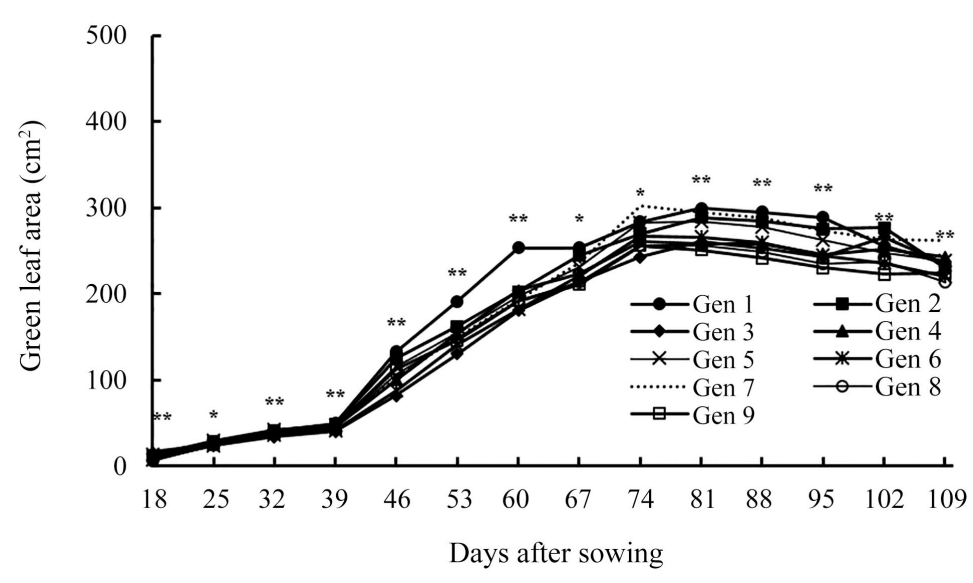

Figure 2. Green leaf area of rice genotypes, in irrigation from 18 to 109 days after sowing (das). Autumn-winter cycle 2015. Campeche, Mexico. ${ }^{* *}(\mathrm{P} \leq 0.01),{ }^{*}(\mathrm{P} \leq 0.05), \mathrm{ns}=$ Not significant. ${ }^{\star}$ The genotypes come from the nurseries of the Latin American Fund for Irrigated Rice (Fondo Latinoamericano para Arroz de Riego, FLAR), Palmira, Colombia.

In drought the statistical analysis detected that highly significant differences $(p \leq 0.01)$ were present between genotypes for all the dates of measurement except at 25 das, when no significant differences were found, and at 46 das when significant differences between genotypes were detected ( $\mathrm{p} \leq 0.05)$ (Figure 3 ). Figure 3 shows the trend of the genotypes in the leaf area; it is observed that starting at 65 das, the leaf area decreases due to the effect of water stress. The average of all the measurements carried out was detected on genotype 1 with the highest values in leaf area, and genotypes 8 and 9 with the lowest values of leaf area.

In the combined statistical analysis of irrigation and drought, highly significant differences were detected between moisture levels of the soil at 32 and 53 das, and from 67 to 109 das. Highly significant differences ( $\mathrm{p} \leq 0.01$ ) were detected between genotypes in all the measurement dates, except at 25 das when significant differences $(p \leq 0.05)$ were found. The leaf area under irrigation was higher in irrigation than in drought, because starting at 65 das the water deficit began at the time of suspending water in the plants in drought treatment (Figure 4).

\subsection{Total Transpiration and Transpiration Efficiency of the Plant}

In irrigation, the statistical analysis of the data detected highly significant differences $(p \leq 0.01)$ between genotypes for transpiration efficiency and total transpiration, average of all the measurements performed. In drought the statistical analysis of the data detected significant differences $(\mathrm{p} \leq 0.05)$ between genotypes for transpiration efficiency and no differences were found for total transpiration per plant. The transpiration efficiency in irrigation was lower $\left(5.3 \mathrm{~g} \cdot \mathrm{kg}^{-1} \mathrm{H}_{2} \mathrm{O}\right.$ $\left.\mathrm{p}^{-1}\right)$, compared to drought $\left(9.8 \mathrm{~g} \cdot \mathrm{kg}^{-1} \mathrm{H}_{2} \mathrm{O} \mathrm{p} \mathrm{p}^{-1}\right)$, genotypes 2,6 and 7 presented the highest TE compared to the rest of the genotypes and in drought it was ge- 
notypes 2 and 7 that outperformed the rest of the genotypes (Table 6). For total transpiration, it was higher in irrigation $(8.1 \mathrm{~kg})$ than in drought $(3.8 \mathrm{~kg})$; in irrigation genotypes 7 and 8 showed the highest values; no significant differences were found in drought (Table 6).

In the combined analysis of irrigation and drought, highly significant differences ( $p \leq 0.01)$ were detected between environments of humidity and between genotypes for transpiration efficiency and total transpiration per plant; highly significant differences were found in the interaction of humidity environments-genotypes for total transpiration per plant and no significant differences were found for transpiration efficiency (Table 7).

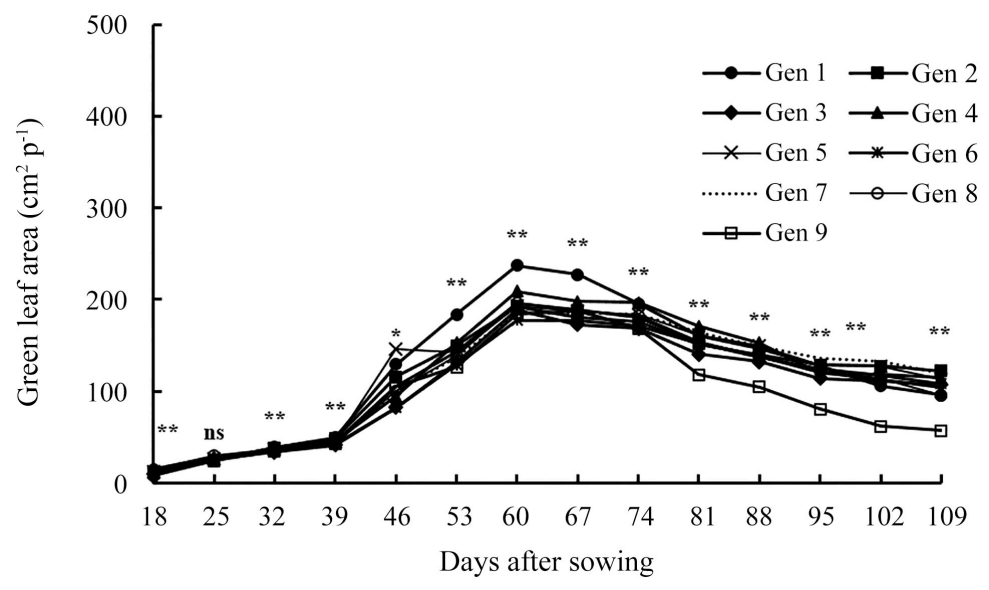

Figure 3. Green leaf area of rice genotypes, in drought from 18 to 109 days after sowing (das). Autumn-winter cycle 2015. Campeche, Mexico. ${ }^{* *}(\mathrm{P} \leq 0.01),{ }^{*}(\mathrm{P} \leq 0.05), \mathrm{ns}=\mathrm{Not}$ significant. ${ }^{*}$ The genotypes come from the nurseries of the Latin American Fund for Irrigated Rice (Fondo Latinoamericano para Arroz de Riego, FLAR), Palmira, Colombia.

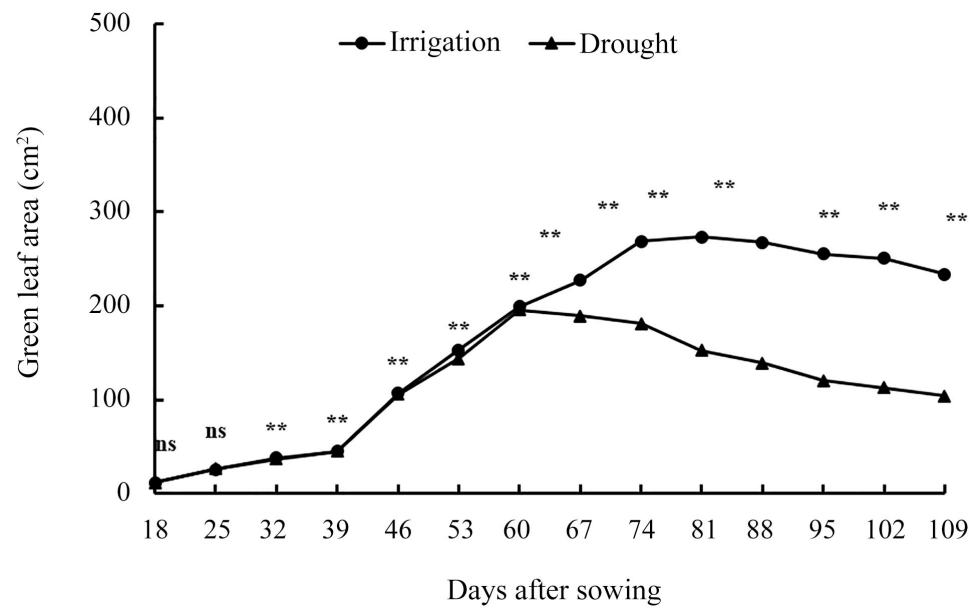

Figure 4. Average green leaf area of nine rice genotypes, in irrigation and drought from 18 to 109 days after sowing (das). Autumn-winter cycle 2015. Campeche, Mexico. ${ }^{* *}(\mathrm{P} \leq$ $0.01),{ }^{*}(\mathrm{P} \leq 0.05), \mathrm{ns}=$ Not significant. ${ }^{*}$ The genotypes come from the nurseries of the Latin American Fund for Irrigated Rice (Fondo Latinoamericano para Arroz de Riego, FLAR), Palmira, Colombia. 
Table 6. Transpiration efficiency to produce total biomass (ETBMT) and total transpiration (TT) of rice genotypes in irrigation and drought. Autumn-winter cycle 2015. Campeche, Mexico.

\begin{tabular}{|c|c|c|c|c|}
\hline \multirow[t]{2}{*}{ No of genotype ${ }^{*}$} & \multicolumn{2}{|c|}{ ETBMT $\left(\mathrm{g} \cdot \mathrm{kg}^{-1}\right)$} & \multicolumn{2}{|c|}{ TT (kg) } \\
\hline & Irrigation & Drought & Irrigation & Drought \\
\hline 7 & $9.0 \mathrm{a}$ & $12.8 \mathrm{a}$ & $6.3 \mathrm{de}$ & $4.1 \mathrm{ab}$ \\
\hline 2 & $7.4 \mathrm{~b}$ & $13.4 \mathrm{a}$ & $8.9 b c$ & $3.7 \mathrm{ab}$ \\
\hline 6 & $6.8 \mathrm{~b}$ & $7.8 \mathrm{~b}$ & $7.2 \mathrm{~cd}$ & $4.4 \mathrm{a}$ \\
\hline 5 & $3.6 \mathrm{ef}$ & $9.9 \mathrm{~b}$ & $11.4 \mathrm{a}$ & $3.6 \mathrm{ab}$ \\
\hline 4 & $4.8 \mathrm{~cd}$ & $9.1 b$ & $7.1 \mathrm{~d}$ & $3.8 \mathrm{ab}$ \\
\hline 1 & $3.5 \mathrm{ef}$ & $8.3 \mathrm{~b}$ & $9.4 \mathrm{~b}$ & $4.2 \mathrm{ab}$ \\
\hline 3 & $5.4 \mathrm{c}$ & $11.0 \mathrm{ab}$ & $5.2 \mathrm{e}$ & $3.2 \mathrm{~b}$ \\
\hline 9 (Control) & $2.6 f$ & $8.5 b$ & $6.5 \mathrm{~d}$ & $3.3 \mathrm{ab}$ \\
\hline 8 & $4.1 \mathrm{de}$ & $6.9 \mathrm{~b}$ & $10.5 \mathrm{ab}$ & $3.6 \mathrm{ab}$ \\
\hline General Mean & 5.3 & 9.8 & 8.1 & 3.8 \\
\hline DMS $(\mathrm{p} \leq 0.05)$ & 1.1 & 4.3 & 1.7 & 1.2 \\
\hline
\end{tabular}

Means with different letter in each column are statistically different (DMS, P $\leq 0.05)$. ${ }^{\star}$ The genotypes come from the nurseries of the Latin American Fund for Irrigated Rice (Fondo Latinoamericano para Arroz de Riego, FLAR), Palmira, Colombia.

Table 7. Transpiration efficiency to produce total biomass (ETBMT) and total transpiration (TT) of the average plant in rice genotypes for irrigation and drought. Autumn-winter 2015 cycle. Campeche, Mexico.

\begin{tabular}{ccc}
\hline Levels of humidity & ETBMT & TT \\
\hline Irrigation & $5.3 \mathrm{~b}$ & $8.1 \mathrm{a}$ \\
Drought & $9.7 \mathrm{a}$ & $3.8 \mathrm{~b}$ \\
DMS $(\mathrm{p} \leq 0.05)$ & 1.3 & 0.9 \\
\hline
\end{tabular}

Means with different letter in each column are statistically different (DMS, $\mathrm{P} \leq 0.05)$. ${ }^{\star}$ The genotypes come from the nurseries of the Latin American Fund for Irrigated Rice (Fondo Latinoamericano para Arroz de Riego, FLAR), Palmira, Colombia.

\section{Discussion}

When comparing the result from nine rice genotypes under conditions of irrigation and drought, it was determined that the genotypes presented high genetic variability in grain yield, biomass, harvest index, number of panicles per plant, number of grains per panicle, and weight of one thousand grains, as well as in days until anthesis, plant height, leaf area, transpiration efficiency and total transpiration, this clearly influenced by the environment, with higher grain yield and its components in irrigation. These results agree with what has been reported by various authors [16] [17] inferring that water stress affected negatively the grain yield in rice cultivation. Of the genotypes studied, lines 2 and 7 stood out both under conditions of irrigation and in drought; it should be mentioned 
that the rest of the advanced lines from FLAR were superior to the control variety and showed adaptation capacity to the zone. It is important to mention that a deficit in water availability causes a decrease in the yield from crops, which was observed in the treatment under drought; when the drought takes place during the flowering period, the water content of the plant cells is reduced, showing symptoms of withering and loss of turgidity that have an impact on the decrease of the plant's gas exchange and photosynthesis, and therefore on the grain yield [9] [10] [18] [19]. The variable height is an aspect to consider in the selection of rice materials, in this experiment it was higher in irrigation than in drought and fluctuated between 67 to $87 \mathrm{~cm}$, the height is associated with lodging problems which is why a taller height represents higher risk in the plant's fall, and what is sought in a material of long and thin grain is a compact height to avoid the loss of the yield from lodging [3] [12]. The least affected variables were days to anthesis (9\%) and days to physiological maturity (12\%), with a difference of eight and five days until flowering and days until physiological maturity, respectively, between irrigation and drought, with them being higher in drought; it was mentioned that drought before flowering delays the anthesis and this delay reduces the percentage of fertile spikelets and full grains [20]; as a result there is a lower photosynthetic rate, relative water content and stomata conductance, and these characteristics show a close relationship with the efficiency in water use, which is reflected in a reduction in grain yield [21]. The importance of leaf development for the crops depends on the interception of solar radiation, key element for the photosynthetic activity that is of vital importance in biomass production with a considerable contribution to the yield [22]. The leaf area in irrigation was higher than in drought, because starting at 65 days after sowing, the water deficit began when watering was suspended in the plants; this is because the plants generally limit the area and number of leaves in response to the water stress to reduce the consumption of water and avoid losses in the yield [23]. The transpiration efficiency was higher under drought $\left(9.8 \mathrm{~g} \cdot \mathrm{kg}^{-1}\right)$ compared to irrigation $\left(5.3 \mathrm{~g} \cdot \mathrm{kg}^{-1}\right)$, and this agrees with what was obtained in other studies where an increase in transpiration efficiency is observed under conditions of water deficit [24] [25]. On the contrary, the total transpiration per plant was $8.1 \mathrm{~kg}$ of water, higher than the treatment under drought that showed $3.8 \mathrm{~kg}$ of water; when the soil moisture begins to decrease, the most effective response of the plant is to reduce transpiration. The first signs of water decrease in the soil are leaf rolling and closing of stomata, and they are the basic mechanism to reduce the impact of drought and are induced first in the vegetative phase and then in the reproductive phase [26] [27].

\section{Conclusion}

The advanced lines of long grain rice generally presented a higher capacity for adaptation to the producing zone of Campeche outperforming the control variety; the genotypes identified as one and two presented higher grain yield and 
its components, as well as plant height, leaf area, transpiration efficiency, both in irrigation and in drought, which makes them strong candidates to be used as progenitors in breeding programs and as commercial varieties in irrigation and drought production systems.

\section{Conflicts of Interest}

The authors declare no conflicts of interest regarding the publication of this paper.

\section{References}

[1] SAGARPA (2015) Agrifood and Fisheries Information and Statistics Service. Statistical Yearbook of Agricultural Production. http://infosiap.siap.gob.mx/gobmx/datosAbiertos.php

[2] Ireta, P.A.R., Garza, L.E.B. Mora, J.S.F. and Peña, B.V.O. (2011) Analysis of Competitiveness of the Rice (Oriza sativa L.) Chain in Southern Morelos, Mexico, with the CADIAC Approach. Agrociencia, 45, 259-265.

[3] Alvarez, H.J.C., Tapia, V.L. Hernández, M.P., Barrios, G.E.J. and Pardo, M.S. (2018) Production Stability of Advanced Rice Lines Long Thin Grain in Michoacán Mexico. Revista Mexicana de Ciencias Agrícolas, 9, 629-637. https://doi.org/10.29312/remexca.v9i3.606

[4] Hernández, A.L. (2016) I. Current Situation of Rice Cultivation in Mexico. In: Hernández, A.L. and Tavitas, F.L., Eds., Rice in México, Mexico, National Institute of Agricultural and Livestock Forestry Research, 1-5.

[5] Jiménez, C.J., Hernández, A.L., Tavitas, F.L. and Cándido, P.A. (2016) Genetic Improvement of Rainfed Rice (NAT) to Counteract the Effects of Climate Change. In: Hernández, A.L. and Tavitas, F.L., Eds., Rice in México, Mexico, National Institute of Agricultural and Livestock Forestry Research, 87-102.

[6] Bernier, J., Atlin, G.N., Serraj, R., Kumar, A. and Spaner, D. (2008) Breeding Upland Rice for Drought Resistance. Journal of the Science of Food and Agriculture, 88, 927-939. https://doi.org/10.1002/jsfa.3153

[7] Kumar, S., Dwivedi, S.K., Singh, S.S., Lekshmy, K.J., Elanchezhian, R., Singh, O.N. and Bhatt, B.P. (2014) Identification of Drought Tolerant Rice Genotypes by Analysing Drought Tolerance Indices and Morpho-Physiological Traits. SABRAO Journal of Breeding and Genetics, 46, 217-230.

[8] Gana, A.S. (2011) Screening and Resistance of Traditional and Improved Cultivars of Rice to Drought Stress at Badeggi, Niger State, Nigeria. Agriculture and Biology Journal of North America, 2, 1027-1031. https://doi.org/10.5251/abjna.2011.2.6.1027.1031

[9] Maisura, Chozin, M.A., Lubis, I., Junaedi, A. and Ehara, H. (2014) Some Physiological Character Responses of Rice under Drought Conditions in a Paddy System. Journal of the International Society for Southeast Asian Agricultural Sciences, 20, 104-114.

[10] Blum, A. (2011) Drought Tolerance: Is It a Complex Trait? Functional Plant Biolo$g y$, 38, 753-757. https://doi.org/10.1071/FP11101

[11] Orona, C.F., Medina, M.J., Cauich, F.M.T., Rocha, J.M.S. and León, I.H.A. (2013) Stability Parameters in Yield and Adaptability for Rice 25 Genotypes of Campeche, Mexico, FYTON ISSN, 82, 255-261. https://doi.org/10.32604/phyton.2013.82.255 
[12] Diaz, S.H., Morejon, R. and Pérez, N.J. (2017) Behavior and Selection of Rice Advanced Lines (Oryza sativa L.) Obtained by Breeding Program in Los Palacios. Cultivos Tropicales, 38, 81-88.

[13] García, E. (1988) Modifications to the Köppen Climate Classification System. 5th Edition, Institute of Geography, UNAM, Mexico DF, 217 p.

[14] Hernández, A.L., Tavitas, F.L. and Alberto, P.C. (2015) Technological Packages for Growing Rice in Mexico. SAGARPA-INIFAP-CONACYT-CIRPAS-Campo Experimental Zacatepec, Technical Brochure No. 87, 85 p.

[15] SAS (2009) The SAS System Release 9.1 for Windows. SAS Institute, Inc., Cary, NC.

[16] Sokoto, M.B. and Muhammad, A. (2014) Response of Rice Varieties to Water Stress in Sokoto, Sudan Savannah, Nigeria. Journal of Biosciences and Medicines, 2, 68-74. https://doi.org/10.4236/jbm.2014.21008

[17] Sabar, M. and Arif, M. (2014) Phenotypic Response of Rice (Oryza sativa L.) Genotypes to Variable Moisture Stress Regimes. International Journal of Agriculture and Biology, 16, 32-40.

[18] Araus, J.L., Slafer, G.A., Royo, C. and Serret, M.D. (2008) Breeding for Yield Potential and Stress Adaptation in Cereals. Critical Reviews in Plant Sciences, 27, 377-412. https://doi.org/10.1080/07352680802467736

[19] Abade, H., Bokosi, J.M., Mwangwela, A.M., Mzengeza, T.R. and Abdala, A.J. (2016) Characterization and Evaluation of Twenty Rice (Oryza sativa L.) Genotypes under Irrigated Ecosystems in Malawi and Mozambique. African Journal of Agricultural Research, 11, 1559-1568. https://doi.org/10.5897/AJAR2016.10895

[20] Pantuwan, G., Fukai, S., Cooper, M., Rajatasereekul, S. and O’Toole, J.C. (2002) Yield Response of Rice (Oryza sativa L.) Genotypes to Drought under Rainfed Lowlands: 2. Selection of Drought Resistant Genotypes. Field Crops Research, 73, 169-180. https://doi.org/10.1016/S0378-4290(01)00195-2

[21] Akram, H.M., Ali, A., Sattar, A., Rehman, H.S.U. and Bibi, A. (2013) Impact of Water Deficit Stress on Various Physiological and Agronomic Traits of Three Basmati Rice (Oryza sativa L.) Cultivars. The Journal of Animal \& Plant Sciences, 23, 1415-1423.

[22] Maqueira, L.L.A., González, D.W., De la Noval, T. and Shiraishi, M. (2014) Evaluation of Growth Variables Behaviors in Varieties of Japonica Rice under Rainfed Favored Condition. Cultivos Tropicales, 35, 43-49.

[23] Cerqueira, F.B., Erasmo, E.A., Silva, J.I.C., Nunes, T.V., Carvalho, G.P. and Silva, A.A. (2013) Competition between Drought-Tolerant Upland Rice Cultivars and Weeds under Water Stress Condition. Planta Daninha, 31, 291-302. https://doi.org/10.1590/S0100-83582013000200006

[24] Changhai, S.B. (2010) Physiological Regulation of High Transpiration Efficiency in Winter Wheat under Drought Conditions. Plant Soil Environment, 56, 340-347. https://doi.org/10.17221/220/2009-PSE

[25] Mohankumar, H.K. (2012) Transpiration Ratio in Sorghum (Sorghum bicolor (L.) Moench) for Increased Water-Use Efficiency and Drought Tolerance. Journal of Arid Land Studies, 22, 175-178.

[26] Bernier, J., Atlin, G.N., Serraj, R., Kumar, A. and Spaner, D. (2008) Breeding Upland Rice for Drought Resistance. Journal of the Science of Food and Agriculture, 88, 927-939. https://doi.org/10.1002/jsfa.3153

[27] Fisher, K.S. and Fukai, S. (2003) How Rice Responds to Drought. In: Fisher, K.S., Lattife, R., Fukai, S., Atlin, G. and Hardy, B., Eds., Breeding Rice for Drought-Prone Environments, International Rice Research Institute, Los Banõs, 32-36. 